University of Pennsylvania Carey Law School

Penn Carey Law: Legal Scholarship Repository

Faculty Scholarship at Penn Carey Law

6-30-2011

\title{
The Mosaic Law in Christian Perspective
}

David A. Skeel Jr.

University of Pennsylvania Carey Law School

Tremper Longman

Westmont College

Follow this and additional works at: https://scholarship.law.upenn.edu/faculty_scholarship

Part of the Biblical Studies Commons, Christianity Commons, Commercial Law Commons, Criminal Law Commons, Family Law Commons, and the Religion Law Commons

\section{Repository Citation}

Skeel, David A. Jr. and Longman, Tremper, "The Mosaic Law in Christian Perspective" (2011). Faculty Scholarship at Penn Carey Law. 367.

https://scholarship.law.upenn.edu/faculty_scholarship/367

This Book Chapter is brought to you for free and open access by Penn Carey Law: Legal Scholarship Repository. It has been accepted for inclusion in Faculty Scholarship at Penn Carey Law by an authorized administrator of Penn Carey Law: Legal Scholarship Repository. For more information, please contact PennlawIR@law.upenn.edu. 


\title{
The Mosaic Law in Christian Perspective
}

\author{
David Skeel \& Tremper Longman
}

\section{Introduction}

Scholars who wish to trace the implications of scripture for contemporary law frequently must look for lessons and hints in passages that lack any explicit legal content. Not so with the final four books of the Pentateuch: Exodus, Leviticus, Numbers, and Deuteronomy. These books are full of law. When Jesus speaks of the law and the prophets, the "law" he has in mind is these books, which contain nearly all of the Mosaic law.

Christians and Christian churches come to the regulations in these books at several removes. God gave the law to a particular community-Israel-- for a particular place. Its regulations included not only criminal and civil law, but also requirements for their worship. For Christians, many of the laws no longer apply, and others do not apply in the same way, as a result of the new covenant inaugurated by Christ's life, death and resurrection.

As we explore the implications of the Mosaic law for contemporary secular law, we therefore must proceed gingerly. The issues we will be considering have vexed theologians and the church for centuries. We cannot claim to resolve them definitively, much less offer a simple blueprint of the implications of the Mosaic law for particular issues, controversial or otherwise. But we believe that serious attention to these four books would force many Christians to radically rethink their understanding of the role and emphasis of secular law.

In the discussion that follows, we first place the Mosaic law in covenantal and New Testament perspective. We then briefly summarize the regulation in each of the four books under consideration.. After noting some of the distinctive characteristics of the laws, we explore their implications for contemporary criminal law; economic and commercial law; and marriage, divorce and sexuality. 


\section{$\underline{\text { The Law in its Context }}$}

\section{Old Testament Context}

In the Old Testament, the law is situated in a literary and theological context. In the first place, law is covenantal. The covenant is a metaphor for God's relationship with Israel that itself is legal. In the past half century, due to comparisons with ancient Near Eastern texts, it has become increasingly clear that covenant (in Hebrew berit) is more specifically described as a treaty. God, the great king, enters into a treaty with his subject people.

In ancient Near Eastern treaties and in biblical covenants, law follows historical prologue. The historical prologue rehearses the beneficial actions that the great king has performed on behalf of the vassal. After the historical review, the great king presents the law that he expects the vassal to obey. In other words, law does not create the relationship, but rather is in response to the previous actions of the sovereign. The law is then followed by sanctions or blessings and curses that follow obedience or disobedience.

The book of Deuteronomy presents Moses’ final sermon to the Israelites before he dies and they enter into the Promised Land. The form of this sermon roughly follows that of a covenant/treaty document since he is exhorting them to reaffirm that relationship established at Sinai (Exodus 19-24), which has become known as the Sinaitic or Mosaic covenant. Here we see the law (Deuteronomy 4-26) following the historical prologue (Deut. 1:9-3:27) and preceding the blessings and the curses (Deuteronomy 27-28). ${ }^{\mathrm{i}}$

Noting the placement of law after the historical review is of important theological significance, reminding Israel that law does not establish relationship with God. On the contrary, God's gracious redemption precedes law and law is a way of expressing gratitude to God. That grace precedes law is concisely illustrated by the fact that the Ten Commandments themselves are preceded by a short historical prologue ("I am the Lord your God, who brought you out of the land of Egypt, out of the house of slavery...,” Exod. 20:1).

However, the fact that the law is followed by blessings and curses also indicates that obedience maintains the divine-human relationship. If Israel disobeys the law, then the curses of the law come into effect. 
The second important matter of context to bear in mind to begin a study of the Old Testament law has to do with the relationship between the Ten Commandments and the case law. The Ten Commandments articulate general ethical principles, while the case law applies those principles to specific cases according to the sociological and redemptive historical situation of Israel. An example would be the case law that states, "When you build a new house, you shall make a parapet for your roof; otherwise you might have bloodguilt on your house, if anyone should fall from it” (Deut. 22:8). This case law applies the principle enunciated by the sixth commandment: "You shall not murder" (Deut. 5:17, see also Exod. 20:13) and applies it to Israelite residential architecture. After all, in ancient Israel the roof was living space and an unprotected roof meant that people could easily fall and get injured or die.

A third important feature of Old Testament law, especially when later considered from the perspective of the New Testament church, is that it is addressed to Israel, which is a nation. That is, the people of God have the form of a nation (in contrast to the present time when the people of God are drawn from many different nations). This transition from the Old to the New Testament will affect how the Old Testament law is appropriated today.

\section{New Testament Context}

The frame for Christian consideration of the Mosaic law comes from Jesus's familiar admonition in the Sermon on the Mount. "Do not think that I have come to abolish the Law or the Prophets,” Jesus said. "I have not come to abolish them but to fulfill them. For truly, I say to you, until heaven and earth pass away, not an iota, not a dot, will pass from the Law until all is accomplished." ii The terms of Jesus's embrace of the law-he will "not abolish” and he will "fulfill"-- rule out two stances toward the Mosaic law that have sometimes proven tempting for Christians. ${ }^{\text {iii }}$ Christians cannot ignore the law, but neither can they simply assume its direct, unfiltered relevance to contemporary concerns. In its most egregious form, the first error is known as Marcionism, after a heretical second century theologian who insisted that the Old Testament was altogether superseded by Christ and has no further relevance. ${ }^{\text {iv }}$ The second, less common error colored theonomy, a small but much discussed theological eruption whose advocates called for the direct application of Old Testament law in a Biblical American polity. ${ }^{\mathrm{v}}$ 
Christ's words not only warn us against either ignoring Old Testament law or applying it in unfiltered fashion. They also characterize the fulfillment of the law as ongoing, a process that Christ has begun but which will continue until "all is accomplished.” To understand what this may mean for contemporary secular law, we begin by identifying some of the focal points, the foundational principles, of the Mosaic law. While others may characterize (and have characterized) the principles that underlie the Mosaic law differently, we focus here on three general themes that run through these books, and provide the foundation for the law. ${ }^{\mathrm{vi}}$

First is the nature of God himself. God is the creator of all things and is completely holy. Although God stands apart from the creation, he is not aloof from it. He has chosen a people for himself, and is in relationship with them. "I the Lord am holy and have separated you from the peoples, that you should be mine," he says in Leviticus. ${ }^{\text {vii }}$ Elsewhere in the Old Testament, Israel is frequently described as God's bride, ${ }^{\text {viii }}$ or as God's child. The books that comprise the Mosaic law admonish Israel to imitate God, as when Israel is instructed to care for the sojourner. "Love the sojourner, Israel is told, “for you were sojourners in the land of Egypt” until God rescued you. ${ }^{\text {ix }}$

Second is the unique nature of the community for whom the Mosaic law was given. The Israel of the Mosaic law is God's chosen people, a nation set apart for himself. They are called to be holy both in their purity and in their separateness from other nations. Their distinctiveness is reflected in God's command that they eschew the practices of the nations around them and that they eat only those foods that are designated as "clean.” God promises to reward Israel’s obedience by showering them with blessings. If Israel disobeys, on the other hand, they will be cursed. The community is responsible for the behavior of its members, and will itself be punished for tolerating lawlessness in its midst. In Leviticus, for instance, God threatens, as the culmination of a stream of horrific punishments for disobedience, to "scatter you among the nations," and "unsheathe the sword after you," so that “your land shall be a desolation, and your cities shall be a waste."x

The third theme is the land. The Mosaic law is framed in anticipation of Israel's entrance into the promised land, and the land is a central concern of the legal framework. Of particular importance are the facts that Israel did not obtain the land through its own prowess or strength; and that its ownership of the land is not absolute. Borrowing from modern property concepts, we 
might call Israel's interest in the land an "obedience-estate." Much as a person who holds a life estate in property owns the property for as long as she lives, after which it reverts to the original owner, Israel was entitled to live peacefully on the land and to enjoy its fruits for as long as she remained faithful to God. But disobedience would terminate Israel’s estate.

The double nature of Israel's ownership — the land was a gift from God, but God remained its ultimate owner-is woven deeply into the Mosaic law. It underscores Israel's dependence on God, and underwrites the law's concerns that the people imitate the holiness of their holy God and that they show the kind of care for sojourners and the vulnerable in their midst that God showed for Israel when they were oppressed in Israel. ${ }^{\mathrm{xi}}$

We subsume in these three themes several major concerns of the Mosaic law that could easily be treated as additional themes. We have not yet mentioned, for instance, the detailed instruction on the dimensions of the tabernacle, the sacrifices, and the responsibilities of the priests in overseeing the sacrifices. The tabernacle and sacrifices lie at the heart of Israel's relationship with God, testifying to God's holiness and defining the community that Israel was called to be. We will consider them in that context-- as the sinews that hold the community together and link it to God.

\section{The Mosaic Law: A Brief Overview}

With the larger themes as a backdrop, we turn now to the law itself. We will begin with a brief survey of the four books under consideration before analyzing the overall structure of the Mosaic law in more detail.

Chapter 20 of Exodus opens with the majestic statement: "And God spoke all these words." Starting with the Ten Commandments, later described as the "ten words," the second half of Exodus is devoted almost entirely to legal regulation. Chapter 20 concludes with an admonition against making gold or silver idols. Chapter 21 begins with a series of regulations about the treatment of slaves, punishments or payments for injuries in a fight or for striking a slave, and restitutionary payments for injuries to someone else's animals. In contemporary terms, the laws just mentioned might be characterized as civil regulation, a mixture of criminal 
law and tort, and tort regulation respectively. The regulation continues (in chapter 22) with a series of tort laws involving damage to a neighbor's property or animals (some of which sound like hypotheticals in contemporary tort scholarship, as with the responsibility of a person who starts a fire for consequent damage to "the stacked grain or the standing grain or the field." These are followed by more criminal laws (including the death penalty for a "sorceress" or anyone who "lies with an animal"), admonitions (to be enforced not by Israel but by God) not to mistreat sojourners, widows, or orphans; not to charge interest in loans to the poor, and not to neglect the obligation to offer their first fruits (whether it be children, animals or crops) to God. Chapter 23 instructs Israel to let the land lie fallow every seventh year, commands rest for all on the Sabbath, and calls for three annual feasts.

Chapters 25-31of Exodus provides detailed instructions for the ark of the covenant and other elements of the tabernacle which was to be the focal point of Israel's camp, their worship, and God's presence during the years in the wilderness; as well as instructions for the construction of the tabernacle itself, for the priests' garments, and for the consecration of the priests. While Moses is on Mount Sinai receiving these instructions, Aaron responds (in chapter 32) to the people's insistence that they be given idols "who shall go before us" by making a golden calf for them to worship. Infuriated when he returns to an orgy of dancing before the gold calf, Moses destroys the two tablets on which God has engraved the Ten Commandments. Moses subsequently persuades God to lift the plague he has inflicted on Israel in punishment, and at God's command makes two new tablets to replace the two he had destroyed (chapter 34). After the startling disobedience of the golden calf, which threatened Israel's very relationship with God, Chapters 35-40 recount in tender detail the construction of the tabernacle, and the making of the elements of the tabernacle and the priestly garments. After this faithful fulfillment of God's instructions, the glory of God fills the tabernacle at the conclusion of Exodus.

Leviticus picks up where Exodus had left off, with the tabernacle newly constructed and filled with the glory of God. Chapters 1-7 outline the sacrifices that Israel is to offer to God, including burnt offerings, grain offerings, peace offerings, sin offerings, and guilt offerings. Moses' brother Aaron and his sons are consecrated as priests to conduct the offerings (chapter 8), and God accepts Aaron's inaugural offering (chapter 9). Once again, disobedience mars Israel's response: Aaron's sons Nadab and Abihu misuse their incense censors, and are consumed by fire 
in punishment (chapter 10). Holiness, a central concern of the sacrificial system, is the dominant theme of the regulations that follow. Chapter 11 details the dietary laws that distinguish Israel from other nations, listing the "clean” animals that Israel is permitted to eat, and the "unclean" ones that are off limits. Chapter 12 prescribes a process of purification for a woman who has just given birth. Chapters 13 and 14 set forth the procedures for determining whether a person (or a house) has a skin disease (or mildew in the case of a house) and thus is unclean, and for purification if the skin disease recedes. Chapter 16 defines the discharges of menstrual blood and semen that make a person unclean, and the procedures for purification. Chapter 18 prohibits Israel from eating blood, or from sexual relations with close relatives. Chapter 19 opens with the instruction that "You shall be holy, for I the Lord your God am holy," and outlines an eclectic series of obligations - to leave the edges of their fields unreaped, for the benefit of the poor or sojourner; not to lie or steal; not to do injustice in court; not to eat blood or sell a daughter as a prostitute; to honor the elderly; and to use just weights. Chapter 20 is primarily concerned with the punishments for violating these obligations—prescribing death for those who sacrifice a child or commit adultery with a neighbor's wife, and instructing that those who turn to wizards or have sex with a sister be cut off from the people.

Chapters 21-23 prescribe the holiness obligations of priests and establish the appointed feasts in the priestly calendar, starting with the weekly Sabbath and Passover.

The case of a woman (whose mother was an Israelite and father an Egyptian) who blasphemed God is recounted in Chapter 24, along with God's instruction to Moses that the blasphemer be stoned by the entire congregation. This is followed by the instruction that anyone who takes a human life must be put to death, and the "eye for an eye” principle of punishment known as lex talionis.

The regulations that follow (in Chapter 25) are devoted to the release of those bound by debt and the restoration to its original owner. Every seventh year is to be a Sabbath year of rest for the land; the fiftieth year is to be the year of jubilee. The jubilee regulations instruct God's people once again to rest the land; provide for redemption of any property that has been sold by an Israelite who becomes poor; call for support of a poor fellow Israelite; and invite redemption of an Israelite who has been sold into servitude. "And if he is not redeemed by these means," the regulations conclude, "then he and his children with him shall be released in the jubilee. For it is 
to me that the people of Israel are servants."xiii Leviticus concludes with the promise of blessings for obedience and punishment for disobedience (Chapter 26), and detailed regulation of vows of gifts to the Lord (Chapter 27).

In Numbers, which recounts Israel's subsequent wanderings in the wilderness, the additions to the Mosaic law are more scattered. Among the notable additions are the establishment of a ritual that allows for the consecration of non-Levites (Num. 6) and an elaborate test to determine whether a jealous husband's wife has committed adultery. ${ }^{\text {xiv }}$ God also instructs Moses to appoint seventy elders to help bear the burden of overseeing the people. Another section prescribes sacrifices to atone for unintentional sins, and recounts Moses' ruling that a man who gathered sticks in violation of the Sabbath must be stoned by the congregation. ${ }^{\mathrm{Xv}}$ Numbers distinguishes between murder and unintentional killing, establishing six cities of refuge to provide safety unintentional manslayers from vengeance seeking family members. Murderers must be put to death, and they cannot be ransomed. ${ }^{\text {xvi }}$ (In the view of some scholars, this prohibition of ransom for murder implies, by negative inference, that other punishments could be and were substituted for the death penalty with crimes other than murder). ${ }^{\text {xvii }}$

Framed as Moses' final sermon as he nears death and Israel prepares to enter the promised land, Deuteronomy retells the events of the three previous books, including God's giving of the Ten Commandments. As in Leviticus, legal regulations run through much of the book (chapters 4-26), often elaborated or articulated differently than in the earlier books. Unlike with the emphasis on holiness in Leviticus, Deuteronomy does not explicitly announce a prevailing theme or themes. But its heart, even more than in Exodus, is the Ten Commandments. The extensive regulatory instructions that come after the Ten Commandments may in fact entail a working out of some of the implications of each of the commandments, ${ }^{\text {xviii }}$ a fact true of all the case law (see above).

Deuteronomy devotes particular attention to the mechanisms of administering justice. Moses instructs the people to appoint judges and officers in each town, which suggests that judging was largely local. If the case was particularly difficult, however, the local officials are instructed to take it to the Levitical priests and central judge. In addition, each of the kings that Israel will later insist on must read the law every day and keep it, so that "his heart may not be lifted up above his brothers.”xix 
Chapters 20-25 set forth a long sequence of regulations, many of which are given in narrative form, apparently as case studies, and few of which are accompanied by explicit punishments. Chapter 20 excuses men who have built a new house, have recently planted a vineyard, are betrothed, or are fearful from battle. Many of the laws concern cleanness and uncleanness, marriage, sexual morality, and protection of the poor and needy from economic oppression. One intriguing regulation involves a mother bird found sitting on her eggs or young. The people are permitted to take the eggs or young for themselves, but must let the mother go. ${ }^{\mathrm{xx}}$

Moses concludes his address with an assurance of blessings if Israel obeys the laws, warnings of the curses for disobedience, a public reading of the law, his farewell song, and a final blessing on the tribes of Israel.

\section{A Few Attributes of the Mosaic Law}

For a contemporary lawyer, the centrality of the Ten Commandments is perhaps the most striking feature of these four books of the Mosaic law. Indeed, as explained above, all the case law is derivative from them. Literally given on a mountain, the commandments seem to rise above the rest of the regulatory landscape, providing the framework for God's covenantal relationship with his people. It is tempting to compare the Ten Commandments to a constitution, and the remaining regulations to the laws that are enacted after a constitution is in place. The analogy must be used carefully. Old Testament ethics courses, particularly in theologically conservative seminaries, sometimes foreground the Ten Commandments so heavily that other dimensions of the Mosaic law disappear. But the Ten Commandments clearly are the touchstone for the regulations as a whole.

Another striking, and similarly well-known, attribute of the Mosaic laws is their mixture of religious and civil regulations. In modern Western legal traditions, religion and civil obligations occupy separate domains, except in the few fraught areas where they overlap. The Mosaic laws govern both domains_-regulating worship as well as criminal law, family law, and torts—although the particular regulations are generally kept separate. 
A third noteworthy attribute is the form the regulations take. The Ten Commandments are direct, absolute, and incontestable. To use the theological term, they are "apodictic.” From the first commandment ("You shall have no other gods before me") to the last ("You shall not covet ...”), the commandments are both literally and figuratively set in stone.

Other commands in the law seem to function more like case studies that are designed to be applied by analogy to other contexts. Here, the theological term is "casuistic." One of the Deuteronomic laws states, for instance: "When you make your neighbor a loan of any sort, you shall not go into his house to collect his pledge."xxii This law seems intended to protect a debtor's dignity, and invites extension to contexts other than the debtor's home, and perhaps to other kinds of transactions as well. ${ }^{\text {xxiv }}$

The distinction must be handled with care. Apodictic regulations may reach beyond their immediate, literal context. We have already noted, for example, that the entire Deuteronomic code (indeed all the case laws) can be seen as extending and applying the principles of the Ten Commandments. But the form of the commands is different. The extension of an apodictic command is like the ripples of a stone thrown into a pond, expanding outward, whereas casuistic reasoning asks whether two distinct things are meaningfully similar. Paul reasons casuistically, for instance, when he cites the command against muzzling an ox that is treading grain as evidence that preachers are entitled to be supported by God's people.

A fourth element is the relationship between particular laws and the remedies attached to them. Some laws do not provide for any explicit remedy. The law (Exod. 21:2-11) mandating that Hebrew slaves be released in the seventh year unless they commit to remain with their master does not prescribe a punishment for violation; presumably, a slave could sue for freedom if he were held for more than six years, but this is nowhere stated in the text. Other laws have very specific criminal or civil penalties. The same sequence of laws in Exodus states that "Whoever steals a man and sells him ... shall be put to death," and that the thief of an ox or sheep "shall repay five oxen for an ox, and four sheep for a sheep.”xxv

Of particular interest here is the large number of commands that do not have a remedy, but include a phrase emphasizing why Israel should honor the command. "You shall not oppress a sojourner," one regulation begins. "You know the heart of a sojourner, for you were sojourners 
in the land of Egypt."xxvi This explanation—or “motive phrase”-highlights a distinction between formal law and moral suasion that we will return to below.

As should be evident even in the handful of examples we have used in this section, the three themes identified earlier run through all of the Mosaic law: God is the creator, he is holy, and he expects holiness from his people. Israel is a unique community that has been set apart as God's people; the regulation of this community is designed to promote its holiness and proper devotion to God. The land is the community's proper home and its regulation reflects the qualities God has and expects from his people, such as justice and care for sojourners and the poor and oppressed.

\section{$\underline{\text { Lessons for Contemporary Issues }}$}

To apply the Mosaic laws to contemporary issues, Christians must come to grips with the implications of Jesus's having come not to abolish the law but to fulfill it. Jesus's sacrifice removes the need for the sacrificial system, for instance, as the book of Hebrews explains at length. But elsewhere the law retains its force, and the principles of law may remain fully relevant even where its specifics have been superceded.

Dating back at least to Calvin, the traditional approach distinguishes among three kinds of law-the moral, civil, and ceremonial. Because the civil and ceremonial law applied to Israel as a nation, these laws were deemed not to be binding on Christians. Moral laws, such as the Ten Commandments, by contrast, are permanent and fully binding (with the possible exception of the fourth commandment concerning the Sabbath, which seems to be a ceremonial law (see also Col. 2:16-17).

The traditional typology neatly simplifies the question of how to apply the Mosaic law after Christ, and it can be defended as a general shorthand. But it is an undependable guide to the application of many parts of the Mosaic law, especially if employed indiscriminately. According to Deuteronomy 24: 6, for instance, "No one shall take a mill or an upper millstone in pledge, for that would be taking a life in pledge.” This looks like a civil law, with particular application to economic relations in Israel, which might suggest that it has been superceded by 
Christ. But the regulation surely has an important moral dimension as well. A loan that is secured by a debtor's millstone would put the debtor's livelihood at risk in the event he was unable to repay. From this perspective, the regulation implicates a creditor's moral responsibilities in credit transactions. As this illustration suggests, the traditional division will not carry us far in our application of the Mosaic law to the contemporary secular law.

In the discussion that follows, we will attempt to draw out some of the implications of the Mosaic law in a more nuanced fashion. In each of three areas-criminal law; economic and commercial regulation; and marriage, divorce and sexuality — we first situate the regulations of the Mosaic law in the context of the three principles we outlined at the outset, analyzing how the rules might have applied in Israel and what the significance of the laws seems to have been. Only after putting the regulations into this larger context do we speculate about the relevance for contemporary law. Because our space is limited, we sketch in loose strokes.

\section{Criminal Law}

Much of the Mosaic law is criminal in nature. As is often noted, the death penalty is called for as a punishment for offenses ranging from murder to blasphemy and a child's disobedience to his parents. Intent is a central concern of the law-as reflected, for instance, in the cities of refuge provided to protect unintentional killers-although unintentional crimes also are treated as crimes. The Mosaic law seems to contemplate that trials will be conducted locally, and it shows particular concern for the nature of the evidence produced, ordinarily requiring the testimony of at least two witnesses (Num. 35:30).

The context of the criminal law is Israel's unique relationship with God as his chosen people. The law reflects God's holiness and his expectation that his people will be holy too. The criminal law therefore covers every aspect of life, including worship, and the penalties are designed both to punish individual wrongdoing and to promote the well being of the community. This last point bears emphasis. Theologians have sometimes suggested that concepts of individual responsibility did not emerge until late in Israel's history. This claim is belied by the Mosaic law itself, as in the command in Deuteronomy that "Fathers shall not be put to death because of their children, nor shall children be put to death because of their fathers. Each one shall be put to death for his own sin."xxviii At the same time, the criminal law was not solely 
concerned with individual responsibility. The call for the community to execute wrongdoers, for instance, underscores that criminal offenses are offenses against the community.

One other oft-noted theme of the criminal laws requires clarification. A key principle of the criminal law_-alluded to by Jesus himself_-is the “eye for an eye” principle known as lex talionis. (As has often been pointed out, in its historical context lex talionis was a comparatively merciful standard that limited retaliation). ${ }^{\text {xxix }}$ The lex talionis most clearly governs physical harms to another person, such as an assault or murder. Its application to other crimes - such as blasphemy, Sabbath breaking, or homosexual sex is less evident.

The land features in the criminal law framework both directly and as a metaphor for the law’s commitment to providing as much protection for the poor or sojourner as for more affluent community members. The cities of refuge provide a zone of safety for those who have unintentionally killed someone. The perpetrators of intentional crimes, on the other hand, are excluded from the camp and from the land. As a metaphor, the land is the place where God's people model the qualities of their God, enforcing justice and promoting the holiness of the community.

The most obvious effect of Christ's coming is to transform the nature of the covenant community. The community's focus shifts away from the land and nation, to Christ and the church, the hearts of the believers themselves. This also severs the link between the community of worship and the apparatus of the state. The extent of the separation should not be overstated. Israel's subjugation by Rome had already created a division between the governing authority and the community of God's people. And Rome would later embrace the church, reuniting church and state. But the transformation brought by Christ complicates the use of the criminal law to police matters of worship. Not only is the church urged to handle grievances internally, as when Paul chastises the Corinthians for suing one another in secular courts, but it becomes much less evident that secular law should be used to prosecute those who blaspheme God or break the Sabbath.

Two attributes of the Mosaic law seem especially relevant in a contemporary context. The first is the link between punishment and specific acts. Because Israel was a much more tightly knit community than a modern nation like the United States, the range of misbehavior that 
could plausibly be policed through criminal law was far broader. The law does indeed speak to a very wide range of behavior — not just the core principles of the Ten Commandments, but the broad spirit of those principles. Yet the formal punishments are almost invariably reserved for clear actions, rather than simply thoughts. Even in Israel, the scope of formal criminal punishment is quite narrow. Contemporary discomfort with the harshness of the penalties can make it easy to overlook the comparative narrowness of the formal criminal law.

The second attribute, already mentioned earlier, is the emphasis on local enforcement. At some points in Israel's history, centralized enforcement would have been quite plausible. And the shift to a monarchy did produce a centralizing tendency. But the model for enforcement of all but the most difficult cases was community-based judging, modeled on the pattern of village elders sitting at the town gate. The shift away from community-based policing and justice in the contemporary United States stands in notable contrast to this biblical pattern. ${ }^{\mathrm{xx}}$

\section{Economics and Commercial Law}

The economic and commercial regulations of the Mosaic law are, like the criminal law, closely linked to God's concern for justice, and foreground even more heavily the emphasis on caring for the poor and the sojourner as God cared for his people during their servitude in Egypt. The central role of the land in this framework calls for particular care as we tease out implications for contemporary law.

The economic regulations of the Mosaic law are framed by reminders that Israel's ownership of the land is conditional on their obedience, and that they are like aliens and sojourners. Rather than being entitled to the entire produce of their acreage, each Israelite family must leave the edges unreaped for the benefit of those in need. Israelites are expected to make interest-free loans to fellow Israelites who are in need, and those who are in servitude for debt are given release in the seventh year. The climax of these regulations is the jubilee outlined in Leviticus 25. In the fiftieth year, debtors must be released from their servitude, and land that an original owner has sold must be returned to its owner. This last requirement ensured (so long as the jubilee was honored-- 2 Chron. 36:21 implies that it was not observed very often) that Israelite families retained the land of their original inheritance and that it did not all end up in the hands of a few giant landowners. 
Jesus draws heavily on the Mosaic law's economic regulations even as he transforms them. When he announces the year of the Lord's favor, invoking the great promise from Isaiah that the year of the Lord's favor has come, Jesus is, most scholars agree, proclaiming a jubilee. $^{\text {xxxi }}$ And the salvation he offers—-with its forgiveness and promise of restoration-is framed in terms of redemption from debt. The economic language attests to the continued relevance of the economic regulations. But the new covenant in Christ changes the context in two respects. The first is that the distinction between Israel and other nations no longer holds in the same way. Christians are called to pay special care to those in the church (as when Jesus says that a cup of cold water given to the least of us ministers to Jesus himself), as the economic regulations directed Israelites to do with their brothers, but Christians also are called to make disciples of all nations. ${ }^{\text {xxxii }}$

Second, the details of the economic regulations reflect the finite amount of land in Israel — which created conditions that economists refer to as "zero sum." An increase in the amount of land owned by one family meant that another family had less, in an economy in which most economic production required land. The jubilee was designed to correct the imbalances that families' disparate fortunes would inevitably create. To determine the jubilee's contemporary implications, we need to take into account the radical changes in context.

Even the most careful scholars often leap from the jubilee to current conditions without fully considering these distinctions. Christopher Wright, whose work has deeply informed our own, writes that "the principles and objectives" of the jubilee "are certainly not irrelevant to welfare legislation or indeed any legislation with socio-economic implications. And indeed, taken to a wider level still,” he continues:

The jubilee speaks volumes to the massive issue of international debt. Not for nothing was the worldwide campaign to see an ending of the intolerable and interminable debts of impoverished nations called Jubilee 2000. ${ }^{\text {xxxiii }}$

This sweeping application comes after a careful analysis of the context of the Biblical jubilee. While we agree that Jubilee 2000 was an admirable campaign, it is important to recognize how far from the original context it was. ${ }^{\text {xxiv }}$ The campaign is aimed at nations, not individual families. To be sure, its enthusiasts believe that debt release will improve the lives of individual 
families. But this often may not be the case. Releasing the obligations of a highly indebted nation may simply benefit an oppressive regime or existing elites.

The call for debt relief also begs the question of, "what next?" Is the debt relief campaign a one time event—a "one off"—or should developing world obligations never be enforceable? The jubilee itself might seem to invite periodic debt remission-perhaps cancelling debts every seven or fifty years, as in the Mosaic law. But here the context is especially important. The seven year period imposed a time limit on human servitude-limiting it to a time period that is substantial but not overwhelming — and the same period for loans to struggling Israelites. Seven years would not have made sense for the repatriation of scarce land to families that had lost it, because the accumulation of land by the wealthy and its loss by struggling families generally occurs over generations, not a few years. Fifty years is a much apter timeline for reestablishing the original ownership patterns.

If one were looking for a time period for loans to developing countries, the appropriate period might well be somewhere between these periods—say twenty or twenty five years. Long enough, the reasoning might go, for the proceeds to be invested or squandered and the consequences to have become clear. A fixed schedule for debt relief would invite predictable responses by lenders: they would insist on higher interest rates and quicker repayment as the year of relief neared. The jubilee anticipates these tendencies and exhorts Israelites to support their struggling brothers even as the jubilee nears. But these are exhortations within the covenant community. They would not have the same resonance as a program for the lenders to different nations.

A twenty year debt jubilee would therefore make it more costly for most nations, and might make it impossible for some, to borrow funds for development. Although some might conclude that cutting off developing countries' access to loans is desirable, it clearly would limit development. The United States depended heavily on foreign borrowing for development in the nineteenth century, as did other developed nations before us.

While the precise terms of the jubilee do not translate well into debt relief and development, the underlying principles - that debt can become oppressive, and the potential for relief is essential—do. The Jubilee movement itself has advocated bankruptcy as a mechanism 
for loosening the fetters of unsustainable debt, and the United Nations has implemented a limited program of targeted relief for "highly indebted poor countries." Each of these can be seen as reflecting the spirit of Biblical treatment of debt.

The same Mosaic law principles apply still more directly to the debt burdens of individual citizens. United States law has long provided bankruptcy relief for debtors who cannot repay their debts, and also allows them to protect property that is seen as essential to their livelihood. In recent years, similar issues have arisen in debates over the regulation of credit cards. In 2009, the United States Congress restricted the fees that credit card companies can impose, and requires them to give consumers longer to repay the monthly bill.

In each of these areas-from an American consumer's credit card bill to a developing nation's debt burden-the guiding principles of the Mosaic law are clearer than implications for specific regulation. Christians might disagree whether a particular credit card law or bankruptcy reform is called for by the principles of the Mosaic law. But the Mosaic law recognizes both the importance of lending and the crushing effect that debt can have, and it is unabashedly paternalistic in its concern for the dignity of the poor.

\section{Marriage, Divorce and Sexuality}

The Mosaic laws on marriage and sexuality combine two qualities that seem, particularly for modern observers, to stand in considerable tension: concern for purity in Israelite’s most intimate relations, and accommodation to practices that are at odds with the moral principles of Scripture. The law demands fidelity in marriage, and threatens severe punishments for adultery and other sexual sin. Yet the Mosaic law also permitted divorce and polygamy.

This tension is not unique in the annals of Israel's relationship with God. God warned Israel against the dangers of establishing a monarchy like those of the surrounding nations. Yet not only did God accede to his people’s demand for a king; he blessed the monarchs who were faithful and incorporated the Davidic line into his plan for restoration and salvation. From this perspective, divorce and polygamy are accommodations to human weakness and, with polygamy especially, to the norms of the Old Testament era. ${ }^{x x v}$ The laws themselves (like the laws on slavery) are particularly concerned with the wellbeing of those who are at risk of oppression. 
Jesus himself pointed out that divorce was permitted only because of the Israelites' weakness, and announced God's expectation of a much higher standard for marriage. Man and wife "are no longer two but one flesh," Jesus said. "What therefore God has joined together, let not man separate." A husband who divorced his wife for any reason other than adultery was himself committing adultery. ${ }^{\text {xxvi }}$

As with criminal law, the shift to a new covenant that is anchored not in a physical location, but in the hearts of men and women, foregrounds the distinction between the state's treatment of marriage and marriage in the church. The history of this tension is long and complex, but the modern American intertwining of church and state oversight of marriage dates back to religious tensions in seventeenth century England. Dissenting Protestants, who previously had insisted that Christian marriage should be entirely within the church, and distinct from the state, embraced governmental reliance on marriages conducted within the church. ${ }^{\text {xxxvii }}$

One plausible conclusion—a conclusion reached by C.S. Lewis on divorce without directing considering the Mosaic law—might be that the Christian churches should promote Biblical principles for marriage within their churches, while abandoning efforts to influence secular regulation of marriage. This stance may be particularly attractive to those who are persuaded the Christians should disengage from politics in the United States, at least temporarily. ${ }^{\text {xxxviii }}$ In its pure form, we think this conclusion goes too far. God is Lord over all creation, not just the church, and Jesus explicitly appealed to the creational order in his teaching on divorce (Matthew 19). Because Christ's teachings are intended principally for the church, however, it also would be a mistake to assume that they should be directly incorporated into secular law.

The acid test of these principles at the present moment is gay marriage. In our view, gay marriage cannot be reconciled with the clear teaching of scripture-both in the Mosaic law and in Christ's fulfillment of the law-that marriage must be between a man and a woman. Heterosexual marriage is part of the creational order, and is a central metaphor for God's relationship with his people. But the Mosaic law also suggests that blanket condemnation of existing cultural norms is not always the appropriate response. From this perspective, domestic partnership law may offer a compelling alternative to either establishing gay marriage or resisting any accommodation to advocates of gay marriage. Provision for health and 
survivorship benefits for domestic partners would reflect the humanitarian principles that lie at the heart of the Mosaic law.

The Mosaic law, as seen in a New Testament perspective, may have similar implications for divorce. In a culture as pluralistic as contemporary America, attempting to replicate in secular law the principles that govern divorce in Christian churches would create intractable enforcement dilemmas and a temptation to flout the law. When divorce is only allowed in cases of adultery, for instance, the state is forced to attempt to police adultery; and couples who wish to divorce may concoct sham sexual misdeeds. Provisions that require a waiting period before a couple can divorce, on the other hand, do not pose these problems. They might discourage some hasty divorces and would nudge the secular law of divorce somewhat closer to Biblical principles of marriage. ${ }^{\text {xxxix }}$

\section{Conclusion}

When Jesus spoke of fulfilling the law and the prophets, he was referring to the Mosaic law, nearly all of which is in the four books under consideration here. The law that governed Israel for centuries can hardly be summarized in a chapter, and the task is complicated still further by the effort to understand its implications for contemporary law.

We have found it helpful to begin by identifying three core principles that provide a foundation for the laws in Exodus, Leviticus, Numbers and Deuteronomy: God's nature, as revealed in Scripture; the nature of Israel; and the role of the land. Using these principles as our starting point, we have briefly explored the regulation of criminal law, economics and commercial law, and marriage, divorce and sexual purity. The general concerns of the law in these areas are much clearer than the precise implications for specific issues. We can state with confidence that the Mosaic law was concerned to protect the most vulnerable Israelites and to encourage marital faithfulness. We have attempted to suggest what this might mean in particular contexts such as credit card reform and divorce laws. While these specific implications will always be subject to debate even among Christians, we hope that identifying and exploring the core concerns may circumscribe the debate, at least a little, and may provide a way of thinking Biblically about contemporary legal issues. 


\section{Endnotes}

i The other elements of a covenant/treaty are also found in Deuteronomy including the introduction of the parties (1:1-5). the mention of witnesses (30:19-20). For a fuller explanation, see M. Kline, Treaty of the Great King (Eerdmans, 1963); K. A. Kitchen, "The Fall and Rise of Covenant, Law and Treaty," TynBul 40 (1989): 118-35; D. J. McCarthy, Old Testament Covenant: A Survey of Current Opinions, $2^{\text {nd }}$ edition (Rome: Pontifical Biblical Institute, 1978).

ii Matthew 5:17-18.

iii In Ephesians 2: 15, Paul describes Jesus as "abolishing the law of commandments and ordinances," but he is speaking of the replacement of the old framework with our justification through Christ, not pronouncing on the question whether any of the laws' principles are still relevant.

iv A less egregious but more common form of ignoring the law is found in dispensationalism.

$\checkmark$ R. Rushdoony, The Institutes of Biblical Law (Craig Press, 1973) and G. L. Bahnsen, Theonomy in Christian Ethics (Craig Press, 1977).

vi Our three themes are loosely patterned on a framework developed by Christopher Wright. Wright refers to them as "paradigms," apparently to assure flexibility in application. Christopher J.H. Wright, Old Testament Ethics for the People of God (Intervarsity Press, 2004).

vii Leviticus 20: 26.

viii Usually implied when Israel is depicted as a adultery (Ezekiel 16 and 23; Hosea 1 and 3); however, see Jer. 2:1-

3.

${ }^{\text {ix }}$ Deuteronomy 10:19.

$x$ Leviticus 26:33.

xi Christopher Wright emphasizes these attributes of the land. Wright, Old Testament Ethics for the People of God.

xii Exodus 22:6.

xiii Leviticus 25: 54-55.

xiv Numbers 5: 5-7 (restitution); 5:11-31).

xv Numbers 15: 22-31 (unintentional sins); 15:32-36 (Sabbath breaker executed).

xvi So Numbers 35:31-32. Proverbs 6:34-35 also implies that the offended husband could substitute a fine for the death penalty, but would likely not be inclined to do so because of his anger.

xvii See, for example, Walter C. Kaiser, Jr., Toward Old Testament Ethics 73 (Zondervan, 1983).

xviii For scholarly interpretation in these terms, see, for example, John H. Walton, "Deuteronomy: An Exposition in the Spirit of the Law," Grace Theological Journal 8 (1987) 213-25. The classic modern work in this vein is Stephen A. Kaufman, "The Structure of the Deuteronomic Law," Maarav 1/2 (1978-79) 105-58.

xix Deuteronomy 17: 18-21.

$x x$ Deuteronomy 22: 6-7.

xxii Deuteronomy 24:10. 
xxiv A Talmudic scholar would question our use of principles to understand the Mosaic law, arguing that it is designed to be understood casuistically. See, e.g., Chaim Saiman, "Jesus' Legal Theory-A Rabbinic Reading," Journal of Law and Religion 23 (2007) 97.

$x \times v$ Exodus 21:16 (man stealing); 22: 1 (ox or sheep).

xxvi Exodus 23:9.

xxviii Deuteronomy 25: 16.

xxix See, for example, David Van Drunen, A Biblical Case for Natural Law (Acton Institute, 2006).

xxx The sad consequences of this shift are a central theme of Bill's Stuntz's late work. See William J. Stuntz, The Collapse of American Criminal Justice (Harvard Press, forthcoming 2011).

xxxi E.g., Wright, Old Testament Ethics for the People of God, p. 206.

xxxii Matthew 10:42 (cup of cold water); 28: 19 (command to make disciples of all nations).

xxxiii Wright, Old Testament Ethics for the People of God, p. 208.

xxxiv Wright does frame the extension of jubilee principles to debt relief as a "paradigmatic" application of the original principles. But it is essential to carefully trace the extension, even if it is acknowledged to be something other than a one-to-one correspondence.

xxxv As Wright argues at length in Wright, Old Testament Ethics for the People of God.

xxxvi Matthew 19: 3-9.

xxxvii John Witte has written the classic history in this area. John Witte, Jr., From Sacrament to Contract: Marriage, Religion and Law in the Western Tradition (Westminster John Knox Press, 1997).

xxxviii See, for example, James Davison Hunter, To Change the World: The Irony, Possibility and Tragedy of Christianity in the Late Modern World (Oxford University Press, 2010).

xxxix For such a proposal, see Elizabeth Scott \& Robert E. Scott, "Marriage as a Relational Contract," Virginia Law School 84 (1998) 1225-1334 . 